\title{
塩化鉄 $(\mathbf{I I I})$ を含む $N$-アルキルアミドの 光分解の ESR による研究
}

(1981 年 12 月 5 日 受理)

栗田雄喜生 ${ }^{*}$ 横 山 泰・城 風 淳 ${ }^{* * *}$ ・藤 井義 久

$\mathrm{FeCl}_{3}$ を含む種々の $N-$ $N$ ルルアミドの光分解機構について, ESR その他の分光学的手法を用い て調べた。

IR, UV によって，アミドは酸素原子で $\mathrm{FeCl}_{3}$ に配位し，電荷移動錯体を形成していることが確認 された。N-プロピルヘキサンアミドの場合, 電荷移動吸収帯 $\left(\lambda_{\max } 312 \mathrm{~nm}\right)$ のとは $4.3 \times 10^{8}$ であっ

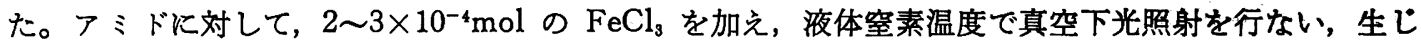
たラジカルを ESR によって同定した。紫外光照射によって，まず，アミド結合の開裂によるアシルラ ジカルが生じた。このラジカルは可視光照射によって脱カルボニルし，アルキルラジカルになった。ア ルキルラジカルが小さい場合には，この試料のアニールによって，アルキルラジカルによる他の分子か らの水素引き抜きが起き，アミドのカルボニル基の $\alpha$-位に不対電子のあるラジカルと、イミニルラシ カルが生成した。イミニルラジカルの検出によって, 最初のアシルラジカル生成のさいにイミンも同時 に生成していることが初めて明らかになった。

\section{1 緒言}

ナイロンは，紫外線照射により分解する1。ナイロンの光分解 機構についてはすでに多くの研究がなされており，開始反応はラ ジカルの生成一すなわち，アミド結合のホモリシス2て5)あるい

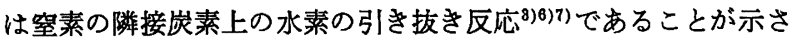
れている。

ナイロンに遷移金属塩を添加したものは, 光照射による分解が 促進されることが知られているき。この方面の研究は少ないが, そのひとつに Pariiskii らの詳しい研究がある。彼らは， $\mathrm{FeCl}_{3}$ を含むナイロン-6 の光分解を ESR を用いて研究し，一つの分 解機構を提案したの)。その機構によると，紫外光照射によってま ず塩素原子が生し，それがフミド窒素に隣接するメチレン基から

横浜国立大学工学部材料化学科, 240 横浜市保土ケ谷区常 盤台

** 旭化成工業株式会社延岡支社レーヨン工場, 882 延岡市中 川原

1) N.S. Allen, J.F. McKellar, J. Polym. Sci., Macromol. Rev., 13, 241(1978).

2) S. R. Rafikov, S. Tsi-Pin, Vysokomol. Soedin., 3, 56 (1961).

3) R. F. Moore, Polymer, 4, 493(1963).

4) G. H. Kroes, Recl. Trav. Chim. Pays-Bas, 82, 979 (1963).

5) H. M. Heuvel, K. C. J. B. Lind, J. Polym. Sci., $A$ 2, 8, 401(1970).

6) V.K. Milinchuk, E. R. Klinshpont, Khim. Vys. Energ., 1, 352(1967).

7) V.P. Kiryukhin, V. K. Milinchuk, ibid., 3, 451(1969).

8) A. T. Betts, N. Uri, Chem. Ind. (London), 1967, 512.
水素を引き抜く。こらしてできたラジカ山が可視光照射やアニー ルによって次々と別のラジカルになる。彼らは，この反応機構を 低分子アミドの場合にまで拡張するため， $N, N$-ジメチルホルA アミド扰よ゙ $N, N$-ジメチルアセトフミドと $\mathrm{FeCl}_{8}$ の系の敞反 応を行なった ${ }^{10) 。 ~}$

著者らは， $N, N$-ジアルキルフミドより，さらKナイロンーに 構造が近い種々の $N$-モノアルキルアミドを用いて， $\mathrm{FeCl}_{3}$ を含 むこれらのアミドの光反応を拈すに ESR によって研究した。こ れらのアミドを用いることにより，1）官能基的炕ナイロンー に近い系でありながら，高分子系にくらべてスベクトルの蟹析が 容易となる，2）アルキル基の長さを変えることによってラジカ ルの同定が確実になる，3） フミド基と $\mathrm{FeCl}_{8}$ の間のモル比が 自由に制御できる，などの利点がある。本研究において， $\mathrm{FeCl}_{8}$ を含むアミドの光分解機構に関して若干の新しい知見を得たので 報告する。

\section{2 実験}

\section{1 装 置}

本研究に使用した装置はつぎのとおりである。

赤外分光光度計：日本分光 A 202

紫外可視分光光度計：島津媻作所 UV-240

電子スピン共鳴四収装置：日本電子 JES-ME-3 X 電子スピン 分光器

9) G. B. Pariiskii, L. M. Postnikov, D. Ya. Toptygin, E. Ya. Davydov, J. Polym. Sci., Polym. Symp., 42, 1287 (1973).

10) G. B. Pariiskii, E. Ya. Davydov, D. Ya. Toptygin, Izv. Akad. Nauk SSSR, Ser. Khim., 1973, 1054. 
Table 1 Amides used in this study

$N$-Methylformamide (NMF) Tokyo Kasei Co.

$N$-Methylacetamide (NMA) Aldrich Co.

$N$-Propylpropanamide (NPP) Synthesized, bp $120 \sim 122^{\circ} \mathrm{C} /$ 20 Torr

*-Propyllmanamide (NPH) Synthesized, bp $162^{\circ} \mathrm{C} / 28$ Torr

柴外腺ランブ：ウシオ電機 USH-500 D 型超高圧水銀灯 2.2 尌 莱

実検に用いたアミドを表 1 に示した。 $N$-メチルホルムアミド (以下 NMF と略記する) は Aldrich 社, $N$-メチルアセトアミ ド (NMA) は東京化成(株) のものをそれぞれ蒸留して用いだ。 $N$-プロピルプロンンンフミド (NPP), $N$-プロピルヘキサンフミド (NPH) は, 相当する市販のカルボン酸を酸塩化物に変換したの ち、ブロピルフミンと樎合して得た。精製は減圧下蒸留をくり返 すことにより行なった。

無水塩化鉄 $\left(\mathrm{FeCl}_{8}\right)$ は和光純薬(株)のすのを用いた。

柴外可視吸収スペクトルの測定に用いたクロロホルムは, 市販 の特級試薬を、フルミナのカラムを通したすのである。

2.3 実鈋方法

2.3.1 赤外吸収 (IR) スベクトル: $N$ メメルアセトアミド (NMA) の IR は KBr 鍉㓮法で湘定した。その他のアミド (NMF, NPP， NPH）は液膜法で，KRS-5 製セルを用いて測定 した。アミドに $\mathrm{FeCl}_{8}$ を添加したもののスペクトルは, 液膜法 で測定した。 $\mathrm{NPH}$ の例を示す。 $\mathrm{NPH} 1.6 \mathrm{~g}$ (10.2 mmol) に, 空素気流下， $\mathrm{FeCl}_{8} 881 \mathrm{mg}(5: 4 \mathrm{mmol})$ を加えて加熱かきまぜ, 溶解きせた。この混合物は $35 \mathrm{wt} \%$ の $\mathrm{FeCl}_{3}$ を含んでおり， ア ミ小のモル比は $\mathrm{FeCl}_{3}$ に対して 1.9 である。

2.3 .2 紫外可視吸収 (UV) スベクトル：測定に用いた七ル は，石英製，セル長 $1 \mathrm{~cm}$ のすのである。 $\mathrm{FeCl}_{3} 19.6 \mathrm{mg}(0.121$ mol) 口ロホルムに溶解して, 全容 $100 \mathrm{~cm}^{3}$ とした（1.21 $\left.\times 10^{-8} \mathrm{~mol} \cdot \mathrm{dm}^{-8}\right)$ (溶液 A)。NPP $0.2 \mathrm{~cm}^{8}$ をクロロホルムに溶 解して全容 $100 \mathrm{~cm}^{8}$ とした $\left(15.5 \times 10^{-8} \mathrm{~mol} \cdot \mathrm{dm}^{-8}\right)$ (溶液 B)。 溶液 $A_{i}$ 2. $5 \mathrm{~cm}^{3}$ に，溶液Bをそれぞれ 1，4，10 扰よび $20 \mathrm{~cm}^{3}$ 加税たすのを，ク口ロルムでそれぞれ全容 $25 \mathrm{~cm}^{3}$ に希釈し， UV スペクトルを湘定した。これらは $\mathrm{FeCl}_{3}$ に対し，それぞれ 5. 14:20.5，51 および 103 倍モルの NPP を含む。

2.3.3 电子スピン共鳴吸収 (ESR) スベクトル: ESR スペク ルル泪定用の試料の調製は, 水および酸素の反応への関与を防ぐ ため,すべて音素気流下で行なった。アミドに $\mathrm{FeCl}_{3}$ を約 $3 \times$ 10-8 $\mathrm{mol} \cdot \mathrm{dm}^{-\mathbf{3}}$ になるように加え，かきまぜ溶解後日本電子(株) 製の石英試料管に入れ，脱気を行なった。NMA の例を示す。 2 $\mathrm{cm}^{8}(26 \mathrm{mmol})$ の NMA K, 空素気流下, $1 \mathrm{mg}\left(6 \times 10^{-3} \mathrm{mmol}\right)$ の $\mathrm{FeCl}_{8}$ を加え, 30 分間加熱かきまぜ行なった。この混合物 を石英試料管にシリンジを用いて入れた。これに, 固化（液体窒 素温度 $) \cdot$ 脱気 $\left(1 \times 10^{-4}\right.$ Torr [1 Torr =133.322 Pa]) ・ 加熱融解 のサイクルを3回くり返したのち，真空下で溶封した。このよう にしてつくった試料の紫外線照射および ESR スペクトルの湘定 は，すへてて液体空素温度で行なった。

フィルターを用いて，適切な波長域の紫外線を試料に照射し， ESR を湘定した。その後この試料に可視光照射，あるいはフ ニールを行ない，ESR を湘定した。フィルターには，UV-D 33
$\mathrm{S}$ ，パイレックスガラス，扰よび $5 \mathrm{~cm}$ 水フィルターを用いた。 可視光照射には, 白熱電灯, あるいは水銀灯の可視域の光を用い た。アニールは, 試料を液体窒素 Dewar 㼚のすぐ上の窒素雲围 気中に 15 秒ないし 2 分間㯰くことにより行なった。

\section{3 結果および考察}

\subsection{IR スペクトル}

ナイロン-6 怙よび $N$-エチルアセトアミドと金属塩の相互作 用の IR による研究は, 1969 年にD Dunn と Sansom によって 行なわれているが11), $\mathrm{FeCl}_{3}$ については詳しくは行なわれていな い。著者らは，アミドの IR スペクトルの $\mathrm{FeCl}_{3}$ 添加による変 化のようすを観察し、アミドと鉄イオンの相互作用を調べた。

アミドにモル比で約 0.5 の量の $\mathrm{FeCl}_{3}$ を加えると，用いたす べてのアミドの場合において, N-H 伸縮振動, アミドーIバン ドおよびアミドーIバンドに顕著な変化が観測された。

図 1 K NPH の場合の変化を示す。これから明らかなよらに, $\mathrm{FeCl}_{3}$ 添加によって, 分子間水素結合をしている $\mathrm{N}-\mathrm{H}$ 伸縮振動 $\left(3280 \mathrm{~cm}^{-1}\right)$ から, 自由 $\mathrm{N}-\mathrm{H}$ 伸縮振動 $\left(3330 \mathrm{~cm}^{-1}\right)$ への約 50 $\mathrm{cm}^{-1}$ の高波数シフト ${ }^{12)}$, アミドーI バンド $\left(1635 \mathrm{~cm}^{-1}\right)$ とアミ ドーII゙ンド $\left(1545 \mathrm{~cm}^{-1}\right)$ の強度の極端な減少, そして新しいバ ンド $\left(1580 \mathrm{~cm}^{-1}\right)$ の出現が見られた。 $\mathrm{N}-\mathrm{H}$ 伸縮振動の高波数シ フトは，〔A]のように分子間で形成されていた水素結合が， $\mathrm{FeCl}_{3}$ の添加により切断されて〔B]のよらになったとして説明 できる。さらに，アミドの酸素で $\mathrm{FeCl}_{3}$ に配位した形に拈いて は, イミニウムエノラート型の極限構造〔C $〕$ の寄与の增大が考 えられる。エノラート型では，C-O 伸縮振動は低波数シフトし， $\mathrm{C}-\mathrm{N}$ 伸縮振動は高波数シフトする ${ }^{12)}$ 。これら二つのシフトした 吸収が重なりあって, 新しい強い吸収帯が $1580 \mathrm{~cm}^{-1}$ に出現し たと結論できる。

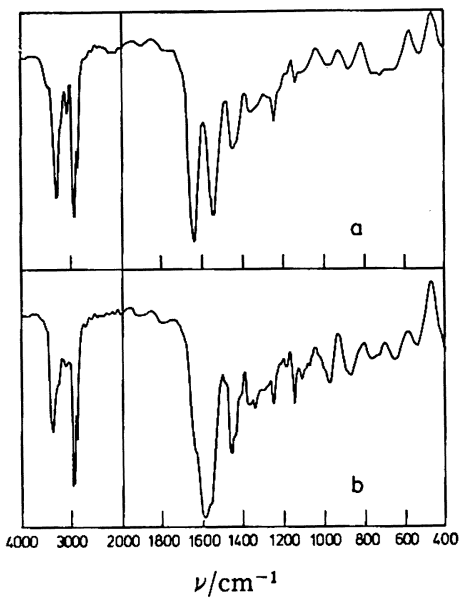

Fig. 1 IR spectra of $\mathrm{NPH}-\mathrm{FeCl}_{3}$ a $: \mathrm{NPH}$

b : $\mathrm{NPH}-\mathrm{FeCl}_{3}$ (molar ratio $1.9: 1$ )

11) P.Dunn, G.F.Sansom, J. Appl. Polym. Sci., 13, 1657 (1969).

12) L. J. Bellamy, "The Infra-red Spectra of Complex Molecules", 3 rd ed., Chapman and Hall, London (1975) p.231. 


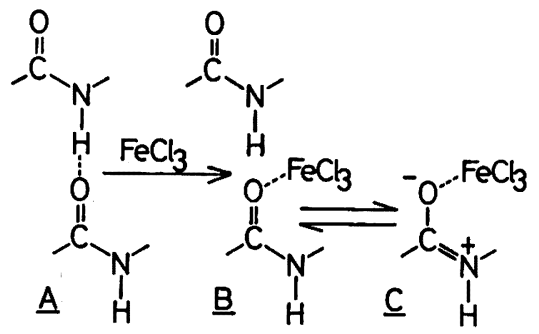

\subsection{UV スペクトル}

金属塩を含むポリアミドの UV スペクトルについては，石谷

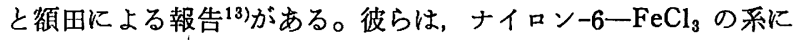
おいて，314，365nm にそれぞれモル吸光係数が数千の吸収が観 測されることを示している。著者らは，ナイロンー6 のモデル化 合物である NPP に関して, $\mathrm{FeCl}_{3}$ 添加による UV スペクトル の変化を調べた。

図 2-a $\mathrm{FeCl}_{3}$ のクロロホルム溶液 $\left(1.21 \times 10^{-3} \mathrm{~mol} \cdot \mathrm{dm}^{-8}\right)$ の UV スペクトルで, $339 \mathrm{~nm}$ に吸収極大 $\left(\varepsilon 4.4 \times 10^{3}\right)$ をるつ。 一方, NPP のクロロホルム溶液 $\left(15.5 \mathrm{~mol} \cdot \mathrm{dm}^{-3}\right)$ の UV スペ クトル（図 2-b）は, $271 \mathrm{~nm}$ に吸収極大（\& 26）を示すたけけで, $300 \mathrm{~nm}$ 以長の領域には吸収をもたない。

$\mathrm{FeCl}_{3}$ の濃度を一定 $\left(1.21 \times 10^{-4} \mathrm{~mol} \cdot \mathrm{dm}^{-3}\right)$ にしておいて， ア ミドの濃度を順次大きくして, UVスペクトルを測定した。 $\mathrm{FeCl}_{3}$ に対して約 5 倍モルの NPP の濃度のとき, $\mathrm{FeCl}_{3}$ の吸収極大が $2 \mathrm{~nm}$ 長波長側にシフトして $341 \mathrm{~nm}$ になった。このシフトは, アミドの濃度増大にしたがってさらに大きくなり，約 20 倍モル の NPP の濃度で $8 \mathrm{~nm}$, 約 50 倍モルで $10 \mathrm{~nm}$, 約 100 倍モル で $11 \mathrm{~nm}$ 長波長側にンフトした。一方，約 20 倍モルの NPP の濃度のとき，新しい吸収極犬が $310 \mathrm{~nm}$ 付近に観測され，NPP 濃度增大にとむなって吸収の強度が增大した。

図 2-c は, 約 100 倍モルの NPP を含む $\mathrm{FeCl}_{3}$ のクロロホ ルム溶液の UV スペクトルである。吸収極大 $312 \mathrm{~nm} に$ に、モ 吸光係数 $4.3 \times 10^{3}$, 吸収極大 $350 \mathrm{~nm}$ にモル吸光係数 $4.6 \times 10^{3}$ のピークをもっている。これらの吸収極大の波長は，石谷と額田 の報告した值 $314 ， 365 \mathrm{~nm}$ に相当すると考えられる ${ }^{13)}$ 。彼らは これら両者ともアミド- $\mathrm{FeCl}_{3}$ 間の電荷移動吸収帯に㷌属してい るが, $\mathrm{NPP}-\mathrm{FeCl}_{3}$ の系で, $\mathrm{FeCl}_{3}$ のみの場合の $339 \mathrm{~nm}$ の吸収 が $350 \mathrm{~nm}$ までシフトし，新しい吸収が $312 \mathrm{~nm}$ に出現したこと は，新しい吸収だけがアミドと $\mathrm{FeCl}_{3}$ による電荷移動吸収帯で あることを示している。

\subsection{ESR スペクトル}

光分解の機構を調べるために, 真空下液体窒素温度でアミド$\mathrm{FeCl}_{3}$ に光照射を行なったときに生じるラジカルを，ESR を用 いて調べた。

NMA の場合は，四3のようなスペクトルの変化を示した。す なわち、 NMA に対してモル比で $2.3 \times 10^{-4}$ の $\mathrm{FeCl}_{3}$ を添加し て調製した試料に，300 nm から $400 \mathrm{~nm}$ の波長の光を液体窒素 温度で 10 分間照射すると，試料は赤褐色になり，図 3-a のよう な ESR スペクトルが得られた。これは $g$ 值 2.0008 , 最大傾斜 幅 $1.5 \mathrm{mT}$ で, アミドの $\mathrm{C}(\mathrm{O})-\mathrm{N}$ 結合が切断されて生成したア セチルラジカルに同定される510)14)。アセチルラジカルは 500 ,

13）石谷 炣, 額田健吉, 日本特許公報, 昭 49-16807.

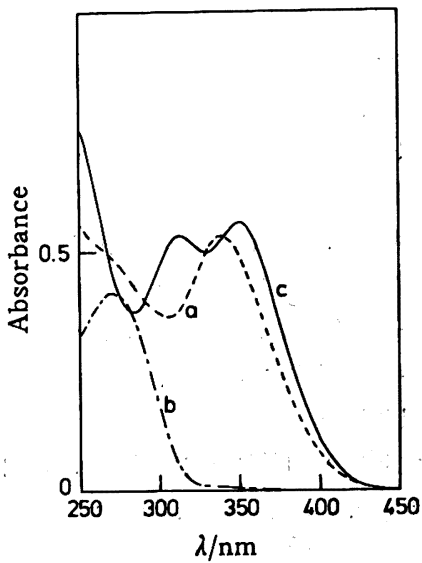

Fig. 2 UV spectra (solvent : $\mathrm{CHCl}_{8}$ )

a (----) : $\mathrm{FeCl}_{\mathrm{s}}\left(12.1 \times 10^{-5} \mathrm{~mol} \cdot \mathrm{dm}^{-8}\right)$

$\mathrm{b}(--\rightarrow):$ NPP. $\left(15.5 \times 10^{-8} \mathrm{~mol} \cdot \mathrm{dm}^{-8}\right)$

c $(\longrightarrow): \mathrm{FeCl}_{8}\left(12.1 \times 10^{-5} \mathrm{~mol} \cdot \mathrm{dm}^{-8}\right)-$ NPP $\left(12.4 \times 10^{-8} \mathrm{~mol} \cdot \mathrm{dm}^{-8}\right)$

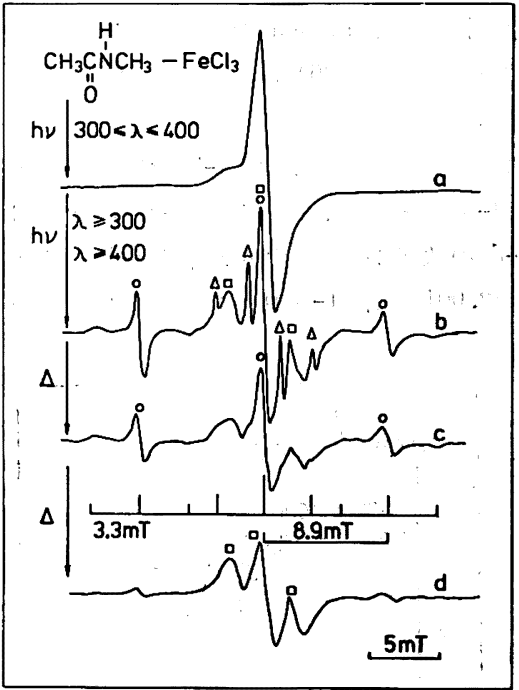

Fig. 3 ESR spectra of irradiated NMA containing $\mathrm{FeCl}_{3}$

$$
\triangle: \mathrm{CH}_{3}, \quad \mathrm{O}: \cdot \mathrm{N}=\mathrm{CH}_{2}, \quad \square: \stackrel{\stackrel{0}{\stackrel{\|}{\mathrm{C}}} \mathrm{CH}_{2} \mathrm{NH}_{3}}{ }
$$

$540 \mathrm{~nm}$ に吸収極大をむつ 14 )。この吸収によって, 試料の赤袖色 を説明することができる。

この赤褐色の試料に $400 \mathrm{~nm}$ 以長の光を照射すると, 試料の赤 褐色が薄くなり，四 3-b のような ESR ズベクトルを与えた。 このとさ，スペクトルの中央にあったアセチルラジカルによるピ ークの絶対強度が弱くなった。

図 3-b のスペクトルは， $\triangle$ 印の四重線（強度比 $1: 3: 3: 1$, 結合定数 $2.36 \mathrm{mT}, g=2.002)$, 中央の $\square$ 印の幅広の三重線，お よび外側の○印のピーク，の三成分にわけることができる。

$\triangle$ 印の四重線は，アセチルラジカルから脱カルボニルして生じ

14) S. Noda, K. Fueki, Z. Kuri, J. Chem. Phys., 49, 3287 (1968). 
たメチルラジカルのすのである14。これはアニールによって消失

し、他の 2 種のピーク強度が増大した（図 3-c）。

さらにアニールを行ならと，因3-d のスペクトルを与えた。

図 3-c のスペクトルから図 3-d のスペクトルを差し引くと, 四 cに書き込んだ棒スペクトルに相当するものが得られる。これ は, $g=2.0018$, 間隔 $8.9 \mathrm{mT}, 1: 2: 1$ の三重線がさらに両側に $3.3 \mathrm{mT}$ にわかれたるので, Banks と Gordy の報告したメタン イミニルラジカル $\left(\cdot \mathrm{N}=\mathrm{CH}_{2}\right)$ のスペクトルとよい一致を示し た ${ }^{15)}$ 。のことから，系内にメタンイミン $\left(\mathrm{HN}=\mathrm{CH}_{2}\right)$ が存在し ていたことが確認された。

図 3-b,c および d の， 口印の三重線のスペクトルは, 強度比 $1: 2: 1$, 結合定数 $2.2 \mathrm{mT}, g=2.0018$ であって, $\dot{\mathrm{C}} \mathrm{H}_{2} \mathrm{C}(\mathrm{O})-$ $\mathrm{NHCH}_{3}$ か $\mathrm{CH}_{3} \mathrm{C}(\mathrm{O}) \mathrm{NHC}_{2}$ の ゙゙ちらかのラジカルのシグナル と考えられる。後者は文献既知で結合定数 $1.889 \mathrm{mT}$ および 1. $895 \mathrm{mT}^{10}$ であるのに対して, $\dot{\mathrm{C}} \mathrm{H}_{2} \mathrm{C}(\mathrm{O}) \mathrm{NH}_{2}$ が $2.15 \mathrm{mT}^{17)}$, $\dot{\mathrm{C}} \mathrm{H}_{2} \mathrm{C}(\mathrm{O}) \mathrm{NHCH}\left(\mathrm{CH}_{3}\right) \mathrm{CO}_{2}{ }^{\ominus}$ か $\left.2.2 \mathrm{mT}^{18}\right)$ であることから,

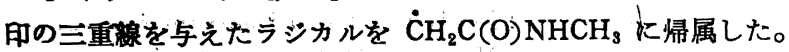
$\mathrm{NPP}-\mathrm{FeCl}_{\mathbf{8}}$ の系に, 液体窒素温度で紫外光を照射すると, NMA の場合と同様に，まずアシルラジカルが生じた。この試料 に可視光を照射すると，図 4-a のよらなスペクトルを与えた。 このスペクトル $(g=2.0026)$ は, エチルラジカルのスペクトル と一致する!‘)。

この試料をアニールすると，圀 4-b を経て図 4-c のように変 化した。四 4-b のスペクトルから四 4-c のスベクトを差し引 くと,図 4-d のようなシグザルが得られる。これは結合定数 $7.8 \mathrm{mT}, g=2.0018$ で, 1-プロパソイミニルラジカルに帰属さ

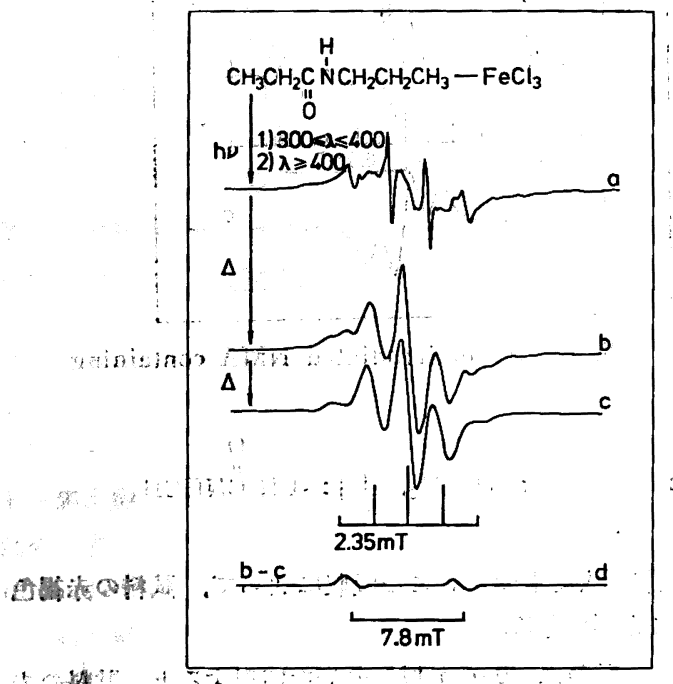

Pig 4 ESR spectra of irradiated NPP containing $\mathrm{FeCl}_{3}$

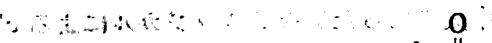

a : $\mathrm{CH}_{8} \mathrm{CH}_{2} \cdot$, c: $\mathrm{CH}_{8} \dot{\mathrm{C}} \stackrel{\text { HCNHCH}}{ } \mathrm{CH}_{2} \mathrm{CH}_{3}$, $\therefore:$ d.: $: \mathrm{N}=\mathrm{CHCH}_{2} \mathrm{CH}_{\mathrm{s}}$

15) D.Banks, W. Gordy, Mal. Phys., 26, 1555(1973).

16) R. Liwingston, H. Zeldes; J. Chem. Phys., 47, 4173 (1967).

17) T. Yonezawa, I. Noda, T. Kawamura, Bull. Chem. . Socz: Jpn., 42, 650(1969).

18) M. D.Sevilla, J. Chem. Phys., 74, 3366(1970),

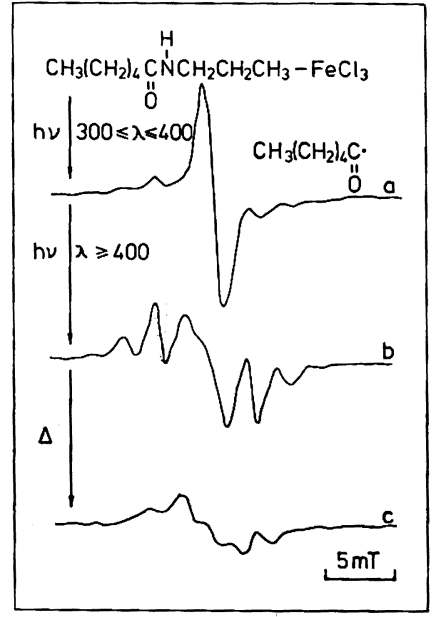

Fig. 5 ESR spectra of irradiated $\mathrm{NPH}$ containing $\mathrm{FeCl}_{3}$

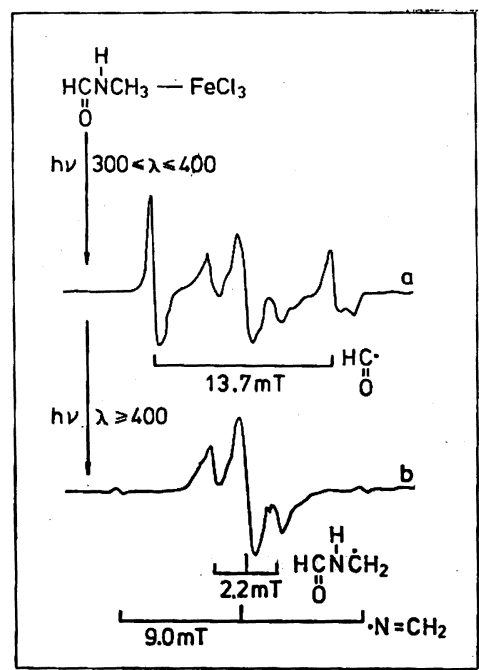

Fig. 6 ESR spectra of irradiated NMF containing $\mathrm{FeCl}_{3}$

れる ${ }^{19)}$ 。

図 4-c のスペクトルは結合定数 $2.35 \mathrm{mT}, g=2.002$, 強度比 $1: 4: 6: 4: 1$ の五重線である。これは結合する水素を 4 個 む つラジカル，すなわちフミドのカルボニル基の $\alpha$-炭素から水素 が引き抜かれたラジカル $\mathrm{CH}_{3} \dot{\mathrm{C}} \mathrm{HC}(\mathrm{O}) \mathrm{NHCH}_{2} \mathrm{CH}_{2} \mathrm{CH}_{3}$ に同定で きる。 $\dot{\mathrm{C}_{2}} \mathrm{CH}_{2}$-型のラジカルは, $1: 3: 4: 4: 3: 1$ の六重線を 与えるので9), $\dot{\mathrm{C}} \mathrm{H}_{2} \mathrm{CH}_{2} \mathrm{C}(\mathrm{O}) \mathrm{NHCH}_{2} \mathrm{CH}_{2} \mathrm{CH}_{3}$ や $\mathrm{CH}_{3} \mathrm{CH}_{2} \mathrm{C}(\mathrm{O})-$ $\mathrm{NHCH}_{2} \mathrm{CH}_{2} \dot{\mathrm{C}} \mathrm{H}_{2}$ である可能性は排除される。

$\mathrm{NPH}$ の場合も, 紫外線照射によって図 5-a のアシルラジカル が生成した。この試料に可視光照射, つついいてアニールを行なう と, 図 5-b,c のよらに変化した。これらはアシルラジカルから 生成したアルキルラジカルのスペクトルであると考党られる。こ れらは，第一級フルキルラジカルと，これが直鎖の中に転位し た ${ }^{20)}$ 第二級アルキルラジカルの混合物のスペクトルであると考兄

19) W.C. Danen, C. T. West, J. Am. Chem. Soc., 96, 2447(1974).

20) M. Iwasaki, K. Toriyama, J. Chem. Phys., 46, 2852 (1967). 


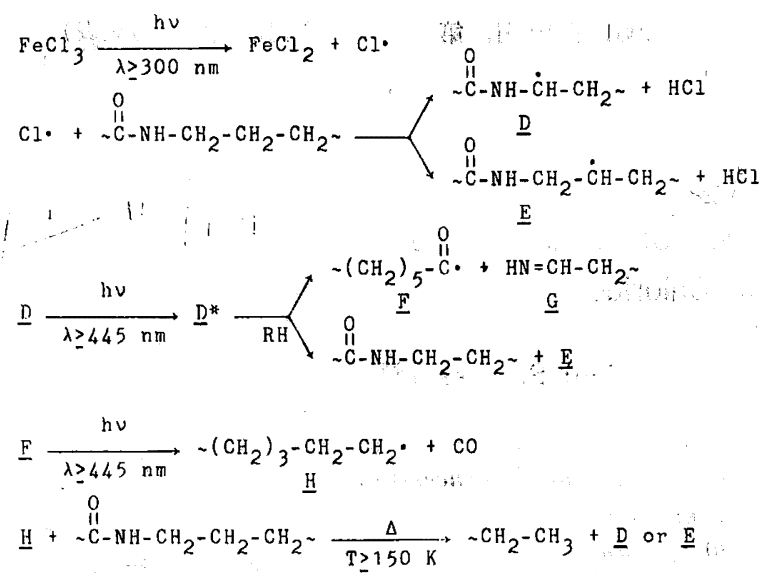

Fig. 7 Pariiskii's mechanism of degradation of Nylon-6$\mathrm{FeCl}_{8}$ complexes

ているが，解析はできなかった。NPH の場合は, イミニルラジ カルおよびアミドのカルボニル基の $\alpha$-位の炭素に不対電子をむ

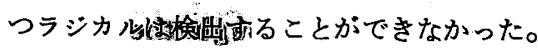

NMF は且記3 種のアミドの場合とは若千異なった挙動を示し た。紫外線照射によって，図 6-a のように結合定数 $13.7 \mathrm{mT}$ の木 ルミルラジカル21)が生じたここの試料の可視光照射によって, 分到間隔 $9.0 \mathrm{mT}$ のメタンイミニルラジカルが生し， HC(O). $\mathrm{NH}^{\circ} \mathrm{CH}_{2}$ と考えられるすののピーク (結合定数 $2.2 \mathrm{mT} T^{16)}$ ) の強 度が增大した（四 6-b)。

\section{4 反态機構}

$\mathrm{FeCl}_{3}$ は紫外光照射により;

$$
\mathrm{FeCl}_{3} \stackrel{h \nu}{\longrightarrow} \mathrm{FeCl}_{2}+\mathrm{Cl} \cdot
$$

のように塩素原子を放出して $\mathrm{FeCl}_{2}$ に還元されることが知られ ている22)。

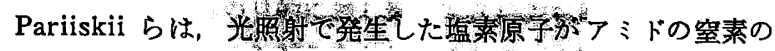
隣接炭素上の水素を引き拔いて有機ラジカルを生成する反応が， $\mathrm{FeCl}_{s}$ を含むナイロン-6 の光分解（図 7 ）の第一段階である， と述へててる9。彼らは実際，約 $313 \mathrm{~nm}$ の波長の光を短時間照 射することによってラジカル [D]（図7）を観湘しており，365 $\mathrm{nm}$ の光によってラジカル [D] からアシルラジカルが生成する ことを推定している。

彼らは, 罒7に拉いて, アシルラジカル生成のさいにイミン [G]が同時に生成すると考えたが，イミンの存在を確認しては いない。今回，著者らの実験に批いて，アニールによってアルキ ルラジカルが減少し，イミニルラジカルの強度が増大したことか ら,アルキルラジカルによってイミンの水素が引き抜かれてイミ ニルラジカルが生成することが明らかになった。この事実は, 系 内にイミンが存在したことを示し, Pariiskii らの反応機構を強 く支持する。

イミニルラジカルは, 水素 (NMF), メチル基 (NMA), およ びェチル基 (NPP) のように, アシル側の置換基が小さい場合に 検出された。しかし、NPH では確認されなかった。これは、イ

21) F. J. Adrian, E. L. Cochran, V. A. Bowers, J. Chem. Phys., 36, 1661(1962).

22) N. Uri, Chem. Rev., 50, 375(1952).

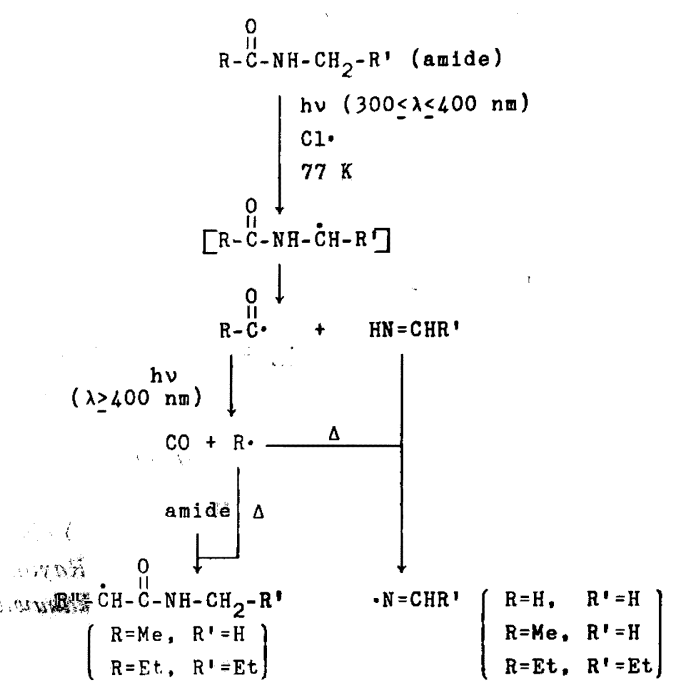

Fig. 8 Mechanism of degradation of amide- $\mathrm{FeCl}_{3}$ complexes

ミニルラジカルのスペクトルがアルキルラジカルの示すスペクト ル中に埋もれてしまったためか, フルキルラジカルが大きいため に動きにくく，したがってイミンに接近してその水素を引き抜く 前に第す級アルキルラジカルに転移してしまったためであろう。 著者らは，後で述べることからも，後者の可能珄が大きいと考え ている。また，NPH でイミニルラジカルが検出されなかったこ とから，ナイロン-6でイミニルラジカルを検出できなかったこ とが説明できる。

Pariiskii らは, アニールによって窒素の $\boldsymbol{\alpha}$-位の炭素上に不対 電子のあるラジカル [D]がふたたび生じることを示唆している が, 著者らは, カルボニルの $\alpha$-位の炭素上に不対電子のある ジカルを観測した。このことについて著者らは以下のように考え ている。

アミド分子自体は, 窒素の $\boldsymbol{\alpha}$-位の炭素上の水素が引き拔かれ やすい。アミドが鉄に配位すると，窒素の非共有電子対がカルボ ニル基の方向に引っ張られ（極限構造〔C]）, 窒素が電子不足の 状態になる。このため, 窒素の $\alpha$-位の炭素も龟子不足になり, 相対的にカルボニルの $\alpha$-位の炭素上の水素の方がラジカルによ って引き抜きを受けやすくなる。したがって，水素原子(NMF), メチルラジカル (NMA), ェチルラジカル (NPP) のようK, 転 移できない，あるいは転移しても同じ第一級である動きやすいラ ジカルが系内に存在すると, カルボニルの $\alpha$-位の炭素上の水素 を引き抜くのであろう。ナイロン-6 および NPH の場合は, フ ルキルラジカルが動きにくいので，他の分子と反応する前に分子 内で水素が転移して安定な第二級アルキルラジカルになることが 考学られる。とくにナイロン-6 の場合には，最初にカルボニル 基の $\alpha$-位に生じたラジカル中心が次々に転移して空素の隣接位 まで移って安定化する ${ }^{20)}$ 。Pariiskii らはこれを钼测したのでは ないか，と著者らは考えている。

以上の結果をまとめて, $\mathrm{FeCl}_{3}$ を含む低分子フミドの光分解機 構を図 8 のように提案する。

ESR 測定にさいし御協力いたたいた本学工学部応用化学科确 口治郎数授括よび八木幹雄博士に感謝する。また, UV スベクト 
ESR Study of Photodegradation of $\boldsymbol{N}$-Alkylamide Containing Iron(III) Chloride

\author{
Yukio Kurita*, Yasushi Yokoyama, Jun-ichi ShirokazE** \\ and Yoshihisa FuJII \\ Department of Materials Chemistry, Faculty of Engineering, \\ Yokohama National University; Tokiwadai, Hodogaya-ku, \\ Yokohama-shi 240 Japan \\ ** Nobeoka Officie, Rayon Plant, Asahi Chemical Industry Co., \\ '. Ltd. ; Nakakawahara, Nobeoka-shi 882 Japan
}

Photodegradation mechanism of $N$-alkylamides ( $N$-methylformamide, $N$-methylacetamide, $N$-propylpropanamide, and $N$-propylhexanamide) containing $\mathrm{FeCl}_{3}$ was studied mainly by means of ESR spectroscopy.

Examination of IR and UV spectra revealed that amides coordinate to $\mathrm{FeCl}_{3}$ through the oxygen atoms. A charge-transfer absorption band was observed $\left(\lambda_{\max } 312 \mathrm{~nm}, \varepsilon=4.3 \times 10^{3}\right)$ in the case of $N$-propylpropanamide- $-\mathrm{FeCl}_{3}$. An ESR study determined structures of radicals generated by photo-irradiation of various kinds of amides containing $\mathrm{FeCl}_{3}$. UV irradiation gave rise to a rupture of the amide linkage to produce an acyl radical. The acyl radical was decarbonylated to become an alkyl radical (or hydrogen atom in the case of $N$-methylformamide) by irradiation of visible light. When the alkyl radical was small (in such cases as $N$ methylformamide, $N$-methylacetamide, and $N$-propylpropanamide), an extraction of hydrogen atom from other molecules occurred during annealing, and two kinds of other radicals were produced : a radical bearing an unpaired electron on a carbon atom adjacent to a carbonyl group,- and an iminyl radical. Detection of the iminyl radical confirmed that a generation of imine was accompanied with the formation of acyl radical at the initial process of UV irradiation.

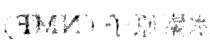

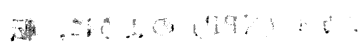

$0,1+x+4$

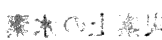

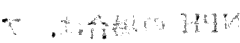

- of

42

$\therefore \therefore$

$11 \%$ 